\title{
INVESTMENT BASED ON INTRINSIC VALUE OF SHARES: DIVIDEND DISCOUNT MODEL IN INDONESIA STOCK EXCHANGE
}

Eddy Sutjipto

Senior lecturer at Department of Accounting, Universitas Semarang, Indonesia

Wawan Setiawan

Senior lecturer at Department of Accounting, Universitas Semarang, Indonesia

\section{Imam Ghozali}

Professor of Accounting at Faculty of Economics and Business, Diponegoro University, Tembalang, Indonesia

\begin{abstract}
The development of the world capital market and especially in Indonesia from the beginning of 2020 is very gloomy. It happened because since the end of December 2019 the Covid-19 pandemic occurred which caused panic among capital market players so that the Composite Stock Price Index (JCI) until at the end of March 2020 had fallen by $-36.67 \%$. There was a correction of $-38,04 \%$ for the average share price of 669 issuers. Conditions like this for long-term investors will be an opportunity to buy up shares, while short-term investors or speculators leave the market.

The calculation of the intrinsic value of shares in this study uses the Dividend Discount Model (DDM). It will take a sample of 49 companies that distributed dividends regularly during the period 2014 - 2019 and have never suffered a loss.

Based on the research results, we can see that there are 42 companies (86\%) that are in an undervalued condition, and only seven companies are overvalued (14\%). Meanwhile, seen from the Margin of Safety (MOS) using the market price basis as of September 30, 2020, 35 companies are worth buying because their MOS is above 30\% and seven companies have MOS less than 30\%. Furthermore, from 35 companies that are eligible to be purchased, there are seven companies, namely HMSP, AALI, ASCII, $B M R I, B B R I, I T M G$ and PTBA.
\end{abstract}

Key words: Intrinsic Value, DDM, MOS, Undervalue and Overvalue.

Cite this Article: Eddy Sutjipto, Wawan Setiawan and Imam Ghozali, Investment Based on Intrinsic Value of Shares: Dividend Discount Model in Indonesia Stock Exchange, International Journal of Management, 11(12), 2020, pp. 998-1009.

http://iaeme.com/Home/issue/IJM?Volume=11\&Issue=12 


\section{INTRODUCTION}

With the Corona-19 virus pandemic which began at the end of December 2019, it has had a massive influence on world capital markets and especially in Indonesia due to panic among capital market players resulting in massive share sales (panic selling), and consequently, stock prices fell. The Indonesia Stock Exchange (IDX) experienced two pressures, namely the negative sentiment of the global market due to Corona-19 and the Jiwasraya insurance case which resulted in the blocking of 800 accounts from several mutual funds. Finally, in endMarch 2020, the Jakarta Composite Index (IHSG) fell by $36.67 \%$, and the average share price of listed companies plunged 38.04\%.

With a deep decline in stock prices or the stock market is bearish because traders are panicking to leave the market by selling their shares. However, for long-term or high-profile investors in Indonesia, the event is an opportunity to buy shares. Because market considers the stock price to be the wrong price or cheap and research results in China show that investors like that because they generally have the power to predict the long term (NG \& WU, 2005).

In general, long-term investors make stock transactions based on the calculation of the intrinsic value of shares. Based on intrinsic value, investors can make the right decisions ( $\mathrm{V} \&$ Paul, 2019). Successful investors will make purchases when the stock price is below intrinsic value because short-term capital market players are panicking leaving the market (Mitchell, 2020) and (Warren, 2016). It happened at the end of March 2020. Long-term investors bought up stocks, and short-term investors left the market so that stock prices slumped. Thus it is natural that many short-term investors do not succeed because it is easy to panic and there is no clear basis for investing so that $85-90 \%$ of investors in Indonesia fail.

The long-term investors consider the determination of the intrinsic value of shares using the Dividend Discount Model method with constant growth to be able to assist investors in making decisions to buy stocks properly. Based on the results of research conducted by researchers, the DDM method provides reliable intrinsic value results (Gacus \& Hinlo, 2018), (Olweny, 2011) and (V \& Paul, 2019). DDM is considered easy and will only be suitable for companies that can pay dividends regularly and will face problems if the company cannot provide dividends consistently (Ivanovski, Narasanov, \& Ivanovska, 2015).Based on the description above, we can see that with the Covid-19 pandemic, many investors panicked so that the stock price on the IDX until the end of March 2020 had decreased quite enormously and $85-90 \%$ of short-term investors had failed. Therefore, the research question that we can ask is, "When the stock price is low, should investors buy shares based on calculating the intrinsic value of shares using the DDM method?"

\section{THEORETICAL REVIEW}

\subsection{Investment}

Capital market players in buying and selling shares use different strategies. In general, the strategies used by capital market players are investing for the long term and daily trading (Mitchell, 2020) and there are three differences, namely trading growth securities, value securities and growth and value securities (Blackburn, Goetzmann, \& Ukhov, 2010). The strategy used by capital market players has a very fundamental difference. Namely that using daily trading strategies or growth requires much time. Because every day we have to pay attention to stock price movements, look for rumours, need to master technical analysis and buy when the stock price is happening an uptrend and sell it in case of a downward trend.

Meanwhile, capital market players who use long-term strategies or value investors buy stocks for the long term. However, when the price drops and selling follow long-term signals 
and do not follow the opinion of analysts because they calculate the intrinsic value of stocks independently. Until the end of 2019, capital market players who used daily trading strategies or securities grew by $85-90 \%$ had experienced failures.

Long-term investors who are commonly referred to as value investors because in carrying out selling, buying, and holding transactions are following the calculation of the intrinsic value of a company's shares. Meanwhile, the method for calculating the intrinsic value of shares according to (Finkle, 2018), there is no one general way that is considered the best way to assess a company because it will depend on the type of industry and stage of growth. Determination of the intrinsic value of shares using a bottom-up approach, namely determining the investment opportunities of a company by analyzing financial statements (Mizrahi, 2007).

The use of the intrinsic value of shares helps the success of investors in buying shares (V \& Paul, 2019). When investors buy shares by making the right decisions, namely when the intrinsic value is more excellent than the current stock price and the margin of safety (MOS) is getting bigger (Mizrahi, 2007). With the more generous the MOS, the risk of a decline in shares after purchase will be protected, so that investors may not suffer losses because there is already a clear calculation basis.

\subsection{Dividend}

Dividends are the benefits provided by the company to shareholders recorded at a cumulative date. The usual investors looking forward to dividend distribution and could be a signal that the company has good prospects or not. For companies that usually pay dividends with large yields, especially those derived from the company's operations, investors will respond positively, marked by an increase in stock prices and stock returns, such as research results from (Safari, 2009), (Arslan \& Zaman, 2014) and (Olweny, 2011). There is no guarantee that companies distribute dividends routinely, and the odds are not the same. Companies in paying dividends every year generally cannot be routine, and the size is different or not constant, and this is the company's way of increasing shareholder value (Lopes, 2012).

The distribution of dividends that are not constant can be caused by the relatively young age of the company so that the profits obtained mostly used for expansion purposes. After being more than ten years old, the company will be able to maintain its superiority so that it can provide predictable dividends quickly (Irons, 2014), (Forsyth, 2019) and (Bhattacharya, Borisov, \& Yu, 2015). In addition to the company phase life, liquidity availability can affect the dividends distribution, the need for funds for debt repayment or expansion (Hassani \& Dizaji, 2013).

\subsection{Return on Equity (ROE)}

Return on Equity (ROE) is a comparison between profit after tax and company equity. The higher the ROE of a company means that the company is well managed by management and the higher the ROE investors will be more interested because they believe they will get high stock returns (Ahsan, 2012). It aligns by (O'Neil , 1990) who has conducted a study for 50 years in America, and the results show that leading stocks generally have an ROE ratio of at least $17 \%$.

We need to mark out companies with high ROE because there may be risks later. With a high ROE, it means that equity ownership is relatively small. Moreover, the company uses more external funds than internal ones. Therefore, if the economic conditions are less favourable, and the profits earned are small, the company will experience financial difficulties. Generally, banking companies in Indonesia have a large ROE because funding 
relies more on loans so that their loans can reach more than five times their equity. However, non-financial companies rarely use external funds that are much larger than their equity.

\subsection{Dividend Discount Model (DDM)}

We can determine the intrinsic value of a company's stock using a variety of methods, but according to (Finkle, 2018), none of the methods is considered the most perfect. The intrinsic value of shares is the actual value of the shares and calculated using the company's fundamental data. This study uses the Dividend Discount Model (DDM) method so that the intrinsic value of the size shares will depend on the company's fundamental data consisting of dividends, ROE, DPR and Stock Return (k).

Researchers more widely use the intrinsic value of stocks with constant growth DDM. This method is known to be obsolete and easy to use because the assumption used is straightforward. Companies distribute dividends regularly every year (Forsyth, 2019), and (Gacus \& Hinlo, 2018) and (V \& Paul, 2019). We can conclude that for companies that can distribute dividends regularly for a certain period. At least the company is already established and able to maintain a position that has a competitive advantage (V \& Paul, 2019) and (Forsyth, 2019). Companies that cannot routinely pay dividends, then the use of the DDM method to calculate the intrinsic value of shares is irrelevant (Ivanovski, Narasanov, \& Ivanovska, 2015).

\section{RESEARCH METHODS}

\subsection{Population and Sample}

The population used in this study are companies listed on the Indonesia Stock Exchange (BEI). Based on data from 2014-2019, the number of companies that distributed dividends on average was 236 companies or $41 \%$ of the total companies listed on the IDX. While the research sample used is companies listed on the Indonesia Stock Exchange (BEI) for the 2014-2019 period, with the following criteria:

- The company distributed dividends consistently during the 2014-2019 period.

- The company during the 2014-2019 period never suffered a loss.

\subsection{Types and Sources of Data}

The type of data in this study is secondary data in the form of financial reports published by companies listed on the Indonesia Stock Exchange (BEI) for the 2014-2019 period. We obtained the data source from the Indonesia Stock Exchange website, namely www.idx.co.id

\subsection{Method of Analysis}

In conducting stock valuation using the DDM method are as follows (Gacus \& Hinlo, 2018) and (Alfredsson \& Lehmann, 2016):

- Calculate the average Return on Equity (ROE) for five years

- Calculating the average Dividend Payout Ratio (DPR) for five years

- Calculating Rate of Return (RR) = 1 - Average DPR

- Calculate the growth $(\mathrm{g})=$ Average ROE x RR

- Determine the dividend projection for five years

Projected dividend $(\mathrm{Dt})=$ Dividend year $0 \times(1+\mathrm{g})$

- Calculating the amount of Return $(k)=($ D $0 / P 0)+g$

- Calculating the intrinsic value $=\mathrm{Dt} /(\mathrm{kg})$ 


\subsection{Model Evaluation}

In this study, we evaluate to determine that the current stock price is still undervalued or overvalued. Shares are said to be under-valued if the current share price is still below the intrinsic value. Conversely, it is said to be over-valued, if the share price is already higher than the calculation of the intrinsic value using the DDM method.

In the next stage, determine the Margin of Safety $(\mathrm{MoS})$ as the basis for the approach to making profitable stock transactions with minimal risks. The calculation of MOS $=1$ - Price / Intrinsic Value or MOS = (Intrinsic Value - Price) / Intrinsic Value. Investors should buy shares to minimize price decline when MOS is greater than 30\%. (Graham \& Dodd, 1934).

\section{RESEARCH RESULTS AND DISCUSSION}

\subsection{Sample Profile}

In this study, using a sample of companies that pay dividends for six years, namely from 2014-2019 and never suffered a loss. Based on these criteria, a sample of 49 companies or 7\% of the total number of companies listed on the Indonesia Stock Exchange (IDX) obtained with the following details.

Table 1 List of sample

\begin{tabular}{|c|c|c|c|}
\hline SECTOR & $\begin{array}{c}\text { Listing } \\
\text { BEI }\end{array}$ & Sample & $\%$ \\
\hline MINING & 50 & 6 & $12 \%$ \\
\hline CONSUMER & 56 & 8 & $14 \%$ \\
\hline INFRASTRUCTURE & 76 & 2 & $3 \%$ \\
\hline TRADE & 168 & 5 & $3 \%$ \\
\hline BASIC-IND & 77 & 5 & $6 \%$ \\
\hline FINANCE & 90 & 14 & $16 \%$ \\
\hline AGRI & 20 & 2 & $10 \%$ \\
\hline MISC-IND & 51 & 2 & $4 \%$ \\
\hline PROPERTY & 83 & 5 & $6 \%$ \\
\hline Total & 671 & 49 & $7 \%$ \\
\hline
\end{tabular}

Source: Secondary data for the period 2014-2019

Based on this table, we can see that the largest number of samples is from the financial sector, namely 14 companies and followed by the consumption sector as many as eight companies and mining six companies. It can reflect that the three sectors during the 20142019 period performed well so that they could provide dividends to shareholders regularly.

Regarding company data that we use as a basis for calculating the intrinsic value of shares using the DDM method, namely in the form of dividends, return on equity (ROE) and dividend payout ratio (DPR). On average, during the 2014-2019 period, they are as follows: 
Investment Based on Intrinsic Value of Shares: Dividend Discount Model in Indonesia Stock Exchange

Table 2 Average of Dividend, ROE and DPR Period: 2014 - 2019

\begin{tabular}{|l|c|c|c|c|}
\hline SECTOR & Sample & Dividend & ROE & DPR \\
\hline MINING & 6 & 348,28 & 4,66 & 0,71 \\
\hline CONSUMER & 8 & 214,43 & 1,48 & 0,57 \\
\hline INFRASTRUCTURE & 2 & 105,62 & 0,18 & 0,55 \\
\hline TRADE & 5 & 209,35 & 0,17 & 0,45 \\
\hline BASIC-IND & 5 & 231,63 & 0,13 & 0,44 \\
\hline FINANCE & 14 & 168,23 & 9,19 & 0,42 \\
\hline AGRI & 2 & 160,83 & 5,18 & 0,39 \\
\hline MISC-IND & 2 & 108,83 & 4,47 & 0,38 \\
\hline PROPERTY & 5 & 86,05 & 0,16 & 0,30 \\
\hline \multicolumn{1}{|c|}{ Total } & 49 & & \\
\hline
\end{tabular}

Source: Secondary data processed for the period 2014-20

With this data, we can see the stability of the stock performance in each sector, explained as follows:

\subsubsection{Dividend}

During the period 2014 - 2019, the mining sector was a commodity business that was able to provide an immense amount of dividends compared to other sectors. It is probably because world oil prices from 2016 - 2019 have increased quite significantly so that profits in the sector have increased. The well-known mining sector companies paid massive dividends, so that the highest average during that period was only PTBA and ITMG, while the other four companies were diminutive. The consumption sector is a defensive company that ranks second in giving large dividends, especially by five companies, namely UNVR, TCID, INDF, ICBP and HMSP.

\subsubsection{Dividend Payout Ratio (DPR)}

The DPR is a comparison between cash dividends per share given to shareholders and the number of earnings per share. The greater the number of DPR, the greater the amount of profit distributed to the holders as dividends. In other words, a company that has one DPR, means that the company gives all of its profits to shareholders and the company is usually favoured by investors, for example, UNVR, TLKM and HMSP, usually the DPR is close to one.

\subsubsection{Return on Equity (ROE)}

ROE is used as an investment reference for investors because a company that has a high ROE means that the company is considered efficient in using its capital for profit. The financial sector occupies the highest position, namely $9.19 \%$. It is because the financial sector, especially banking, generally relies more on loans that are much larger than their capital. Hence, it is natural that if the profits continue to increase, the ROE is large. The second position is the Agriculture sector with an ROE of 5.18\% and followed by the Mining sector $4.66 \%$ and the Misc-industry sector $4.47 \%$. Meanwhile, the sectors that had slumped were Infrastructure, Trade, Property and Basic-Industry with an ROE of less than 1. 


\subsection{Result of Shares Intrinsic Value Calculation}

Theoretically, the data used for six years or the 2014-2019 period for companies that regularly pay dividends we can consider as companies that have tested their performance with uncertain environmental conditions. Thus, although the method of calculating the intrinsic value is straightforward and even outdated, the possible results can still be used as a reference for investors or novice capital market players in investing in stocks.

The share price used to determine the undervalued or overvalued stock price is the end price of September 2020 because the dividend distribution for the 2019 financial year distributed that month. With the Corona-19 virus, the share price when compared to the closing price at the end of December 2019 still experienced an average decline of $-23.29 \%$. We consider the stock price as undervalued if the result of the calculation of the intrinsic value is greater than the share price and vice versa, that is if the overvalued means the intrinsic value is smaller than the current stock price.

Meanwhile, the concept of Margin of Safety (MOS) for investors or value investors is a recommended strategy in order to obtain cheap shares and sell at reasonable prices. To apply this concept, it is better if it is safe or the stock price is not likely to fall further, namely a minimum MOS of $30 \%$. It means that the current share price is still $30 \%$ below the intrinsic value of the shares.

Following are the details of the calculation of overvalued shares, namely TURI, MKPI, INKP, ASBI, MEGA, ACES, UNTR and MYOH. The number of overvalued stocks is still very few and generally stocks with a relatively small market capitalization. Compared to the stock price at the end of December 2019, the share price has increased on average by $13.88 \%$. Thus, investing in overvalued stocks is not quite right, because the stock price may decline or if it rises, it may not be optimal.

Furthermore, the number of undervalued stocks is still very much, and this is an opportunity for investors to choose stocks that are worth buying because, in December, there is usually a Window Dressing action.

Table 3 List of Undervalue Stock

\begin{tabular}{|c|c|c|c|c|c|}
\hline No & Code & Sector & $\begin{array}{c}\text { Intrinsic } \\
\text { Value } \\
\text { (IV) }\end{array}$ & $\begin{array}{c}\text { Price - } \\
30 / 9 / 2020\end{array}$ & $\begin{array}{l}\text { Undervalue/ } \\
\text { Overvalue }\end{array}$ \\
\hline 1 & LSIP & Agri & 1.485 & 905 & Undervalue \\
\hline 2 & AALI & Agri & 15.450 & 10.175 & Undervalue \\
\hline 3 & WTON & $\begin{array}{l}\text { Basic- } \\
\text { Industry }\end{array}$ & 450 & 222 & Undervalue \\
\hline 4 & INTP & $\begin{array}{l}\text { Basic- } \\
\text { Industry }\end{array}$ & 19.000 & 10.400 & Undervalue \\
\hline 5 & SMGR & $\begin{array}{l}\text { Basic- } \\
\text { Industry }\end{array}$ & 12.000 & 9.175 & Undervalue \\
\hline 6 & FASW & $\begin{array}{l}\text { Basic- } \\
\text { Industry }\end{array}$ & 7.700 & 6.700 & Undervalue \\
\hline 7 & TCID & Consumer & 11.000 & 6.300 & Undervalue \\
\hline
\end{tabular}


Investment Based on Intrinsic Value of Shares: Dividend Discount Model in Indonesia Stock Exchange

\begin{tabular}{|c|c|c|c|c|c|}
\hline 8 & SIDO & Consumer & 1.275 & 745 & Undervalue \\
\hline 9 & HMSP & Consumer & 2.100 & 1.400 & Undervalue \\
\hline 10 & CINT & Consumer & 302 & 236 & Undervalue \\
\hline 11 & INDF & Consumer & 8.300 & 7.150 & Undervalue \\
\hline 12 & ICBP & Consumer & 11.150 & 10.075 & Undervalue \\
\hline 13 & KLBF & Consumer & 1.620 & 1.550 & Undervalue \\
\hline 14 & UNVR & Consumer & 8.425 & 8.100 & Undervalue \\
\hline 15 & BBTN & Fincance & 2.300 & 1.200 & Undervalue \\
\hline 16 & BBNI & Fincance & 8.500 & 4.440 & Undervalue \\
\hline 17 & BDMN & Fincance & 4.125 & 2.170 & Undervalue \\
\hline 18 & BMRI & Fincance & 8.300 & 4.960 & Undervalue \\
\hline 19 & BBRI & Fincance & 4.800 & 3.040 & Undervalue \\
\hline 20 & $\mathrm{ADMF}$ & Fincance & 11.225 & 7.225 & Undervalue \\
\hline 21 & BJBR & Fincance & 1.250 & 870 & Undervalue \\
\hline 22 & BJTM & Fincance & 725 & 510 & Undervalue \\
\hline 23 & BFIN & Fincance & 570 & 406 & Undervalue \\
\hline 24 & BBCA & Fincance & 34.700 & 27.100 & Undervalue \\
\hline 25 & ASRM & Fincance & 2.000 & 1.725 & Undervalue \\
\hline 26 & ABDA & Fincance & 6.975 & 6.600 & Undervalue \\
\hline 27 & PGAS & Ifrastructure & 2.170 & 925 & Undervalue \\
\hline 28 & TLKM & Ifrastructure & 3.970 & 2.560 & Undervalue \\
\hline 29 & ELSA & Mining & 305 & 194 & Undervalue \\
\hline 30 & ADRO & Mining & 1.625 & 1.135 & Undervalue \\
\hline 31 & ITMG & Mining & 11.650 & 8.150 & Undervalue \\
\hline 32 & PTBA & Mining & 2.725 & 1.905 & Undervalue \\
\hline 33 & BSSR & Mining & 1.820 & 1.410 & Undervalue \\
\hline 34 & ASII & Misc-Ind & 7.300 & 4.460 & Undervalue \\
\hline 35 & AUTO & Misc-Ind & 1.240 & 825 & Undervalue \\
\hline 36 & ADHI & Property & 1.175 & 500 & Undervalue \\
\hline 37 & PTPP & Property & 1.585 & 825 & Undervalue \\
\hline 38 & WIKA & Property & 1.990 & 1.095 & Undervalue \\
\hline 39 & NRCA & Property & 385 & 290 & Undervalue \\
\hline 40 & AKRA & Trade & 3.950 & 2.550 & Undervalue \\
\hline 41 & ASGR & Trade & 950 & 725 & Undervalue \\
\hline
\end{tabular}

Source: Secondary data processed for the period 2014-2019 
The number of undervalued shares until the end of September 2020 was still vast, namely 41 companies or $84 \%$ of the total sample. It shows the share price decrease by an average of $37.96 \%$ from the end of 2019 until its peak on March 24, 2020. Moreover, until the end of September, the share price has still decreased by $-23.29 \%$. It happens because it is still uncertain when the Covid-19 pandemic will end. While the price increase from December 2019 to September 2020, namely Agriculture rose 31.23\%, Misc-Industry 21.89\%, Property $19.47 \%$, Finance $17.68 \%$, Infrastructure $11.49 \%$, Basic Industry 9.75\%, Consumer Goods 9.22\% and Mining 6.96\%.

Meanwhile, if viewed from the average MOS which is still above $30 \%$, namely Infrastructure (46.44\%), Property (43.76\%), Agriculture 36.19\%, Miscellaneous Industry $36.19 \%$, Basic Industry $33.11 \%$ and Finance $32.12 \%$, although the average MOS is still large, it does not mean that all shares in the sector are worth buying.

Companies whose MOS value is still above $30 \%$ are in all sectors. However, most of them are from the Finance sector, and many of their shares are in the Blue Chip category because their market capitalization value is above Rp 50 trillion.

\subsection{Investment decision}

Investors usually pay attention to the company's fundamentals, business prospects and its management for selecting the appropriate shares to buy. The following are stocks that are worth buying concerning undervalued stocks and their first semester 2020 performance.

Table 4 List of Stocks worth Buying

\begin{tabular}{|c|c|c|c|c|c|c|c|c|}
\hline \multirow{2}{*}{ No } & \multirow{2}{*}{ Code } & \multirow{2}{*}{ Sector } & \multicolumn{3}{|c|}{ Rata-rata 2014-2019 } & \multicolumn{3}{|c|}{ Januari - 30 Juni 2020} \\
\cline { 5 - 9 } & & & ROE & DER & EPS & ROE & DER & EPS \\
\hline 1 & HMSP & Consumer & $38,2 \%$ & 0,5 & 91,5 & $36,7 \%$ & 0,6 & 84,0 \\
\hline 2 & AALI & Agri & $10,3 \%$ & 0,5 & 836,8 & $4,2 \%$ & 0,4 & 407,2 \\
\hline 3 & ASII & Misc-Ind & $14,8 \%$ & 0,9 & 457,0 & $13,7 \%$ & 0,8 & 562,0 \\
\hline 4 & BMRI & Fincance & $15,1 \%$ & 5,6 & 647,0 & $11,5 \%$ & 6,0 & 441,3 \\
\hline 5 & BBRI & Fincance & $18,4 \%$ & 6,2 & 232,6 & $11,2 \%$ & 6,2 & 166,1 \\
\hline 6 & ITMG & Mining & $18,7 \%$ & 0,4 & $2.736,0$ & $6,6 \%$ & 0,4 & 882,0 \\
\hline 7 & PTBA & Mining & $24,9 \%$ & 0,3 & 543,3 & $16,3 \%$ & 0,7 & 230,0 \\
\hline
\end{tabular}

Source: Processed secondary data

We consider a company as good if the resulting ROE is high enough because the company can manage its capital efficiently. Based on these data, we can see that the ROE and EPS mining sector experienced the largest decline. Starting from the decline in EPS, namely semester I 2020 compared to the average $2014-2020$ for ITMG $-67.76 \%$ and PTBA $-57.67 \%$. As a result, the ROE of ITMG and PTBA decreased by $-12.05 \%$ and $-8.6 \%$.

Finance sector shares decreased in EPS between the period 2014-2019 and 2020 quite large, especially BMRI (-31.8\%) and BBRI (-28.57\%). Meanwhile, the ROE decreased by $7.17 \%$ for BBRI, and BMRI only decreased by $-3.58 \%$. This decline is likely because many companies experienced a decline in sales due to Large-Scale Social Restrictions (PSBB) and Bank Indonesia policies that reduced 7-day repro to 4\%. Meanwhile, the DER is still relatively high, which is above 6 . However, the two banks still have good prospects because they have the largest market capitalization in Indonesia, and the merger of Syariah Bank will have a better impact. 
As for HMSP shares, there are still good prospects if the increase in excise is not too large, and the shares usually give all the profits to shareholders. AALI's shares have a reasonable prospect because CPO prices have started to increase, and ASII's shares will improve if the National and World economies have started to recover.

\section{CONCLUSION}

The calculation of the intrinsic value of shares using the DDM Constant Growth approach is the easiest or simplest method. It only uses fundamental company data in the form of dividends, ROE and DPR as well as stock prices on specific dates. Thus, it does not use assumptions related to external factors such as interest rates. Although the method is simple, the results of the calculation of the intrinsic value of the shares we can use to determine whether a stock is still undervalued or overvalued. These conclusions are often used as the basis for successful buying and selling transactions by investors.

Based on the calculation of the intrinsic value of shares using a sample of 49 companies, the following results we can obtain:

\section{- Undervalued company}

There are 41 companies whose intrinsic value is still more notable than the stock price or undervalued as of September 30, 2020, but with MOS $>30 \%$ there are 26 companies, and whose MOS is less than $30 \%$ there are 15 companies.

\section{- Overvalued company}

An overvalued company means that the share price as of September 30, 2020, is already higher than the calculation of its intrinsic value. It means that the shares are not suitable to be purchased because investors if they buy and save for up to one year, are likely only to receive dividends and will not get capital gains.

\section{- Worth buying}

Meanwhile, there are seven shares whose MOS is more than $30 \%$ and are feasible to buy, consisting of HMSP, AALI, ASCII, BMRI, BBRI, ITMG and PTBA shares. Shares that are worth buying because of their excellent fundamental factors, namely high ROE and EPS, low DER and BBRI, BMR, PTBA shares in 2019 received fair GCG implementation assessment, or Indonesia Most Trusted Companies

\section{RECOMMENDATION}

For further research, it is better if using more samples with the research period shortened to 3 or 4 years and the assumptions used in the DDM method are not constant growth and pay attention to the level of capital costs.

In buying stocks, we should pay attention to the difference in intrinsic value and large share prices (MOS> 30\%), high ROE, low DER and good sector prospects.

\section{REFERENCES}

[1] Ahsan, A. M. Can Return on equity be used to predict portfolio performance? Economics, Management, and Financial, 7(2), 2012, 132-148. Retrieved from https://www.researchgate.net/publication/258341502_Can_Return_on_equity_be_used_to_pre dict_portfolio_performance 
[2] Alfredsson, A., \& Lehmann, C. Intrinsic Equity Valuation: An Empirical Assessment of Model Accuracy. Bachelor thesis, 15 ECTS, Södertörn University, Business Administration, 30. 2016. Retrieved from https://www.divaportal.org/smash/get/diva2:939272/FULLTEXT01.pdf

[3] Arslan, M., \& Zaman, R. Impact of Dividend Yield and Price Earnings Ratio on Stock Returns: A Study Non-Financial listed Firms of Pakistan. Research Journal of Finance and Accounting, 5(19)2014. Retrieved from https://core.ac.uk/download/pdf/234630187.pdf

[4] Bhattacharya, U., Borisov, A., \& Yu, X. Firm Mortality and Natal Financial Care. Journal of Financial and Quantitative Analysis, 50(1-2),2015, 61-88. doi:https://doi.org/10.1017/S0022109014000581

[5] Blackburn, D., Goetzmann, W., \& Ukhov, A. Trading Behavior of Style and Multi-Style Investors. $\quad$ Rotterdam.2010. Retrieved from https://www.researchgate.net/publication/242581547

[6] Finkle, T. Warren E. Buffett: Entrepreneur, investor, and philanthropist. Journal of Business Cases and Applications, 19, 2018. Retrieved from https://pdf4pro.com/view/warren-e-buffettentrepreneur-investor-and-2d00e.html

[7] F Bhattacharya, U., Borisov, A., \& Yu, X. Firm Mortality and Natal Financial Care. Journal of Financial and Quantitative Analysis, 50(1), 2015, 61 - 88. doi:https://doi.org/10.1017/S0022109014000581

[8] Forsyth, J. An alternative formula for the constant growth model. Journal of Economics, Finance and Administrative Science, 24(48),2019, 221-240. doi:10.1108/JEFAS-07-20180067

[9] Gacus, R. B., \& Hinlo, J. The Reliability of Constant Growth Dividend Discount Model (DDM) in Valuation of Philippine Common Stocks. International Journal of Economics \& Management Sciences, 7(1), 2018, 2-9. doi:10.4172/2162-6359.1000487

[10] Graham, ., \& Dodd, D. Security analysis. New York, 1934. Whittlesey House, McGraw-Hill Book Co.

[11] Hassani, M., \& Dizaji, F. K. Life cycle theory and dividend payout policy: Evidence from Tehran Stock Exchange. Management Science Letters,2013, 2631-2634. doi:10.5267/j.msl.2013.09.005

[12] Irons, R. Enhancing the Dividend Discount Model to Account for Accelerated Share Price Growth. Journal of Accounting and Finance, 14(4),2014, 153-159. Retrieved from https://www.researchgate.net/publication/267926904_Enhancing_the_Dividend_Discount_Mo del_to_Account_for_Accelerated_Share_Price_Growth/link $/ 545 \overline{\mathrm{d}} 32 \mathrm{~d} 90 \mathrm{cf} 27487 \overline{\mathrm{b}} 44 \mathrm{~d} 4 \mathrm{be} 5 / \mathrm{do}$ wnload

[13] Ivanovski, Z., Narasanov, Z., \& Ivanovska, N. Accuracy Of Dividend Discount Model Valuation At Macedonian Stock- Exchange. Economy and Business Journal of International Scientific Publications, 9(1), 2015, 73-83. Retrieved from https://ideas.repec.org/a/isp/journl/v9y2015i1p73-83.html

[14] Lopes, D. Dividends as added attraction to investors. 2012, doi:https://business.inquirer.net/55267/dividends-as-added-attraction-to-investors 
Investment Based on Intrinsic Value of Shares: Dividend Discount Model in Indonesia Stock

\section{Exchange}

[15] Mitchell, C. Pros and Cons of Day Trading Versus Long-Term Investing. (M. J. Boyle, Ed.), 2020, Retrieved from The Balance: https://www.thebalance.com/day-trading-versus-longterm-investing-4139868

[16] Mizrahi, C. Getting Started in Value Investing. Wiley.2007.

[17] NG, L., \& WU, F. The Trading Behavior of Institutions and Individuals in Chinese Equity Markets. SSRN Electronic Journal.2005, doi:10.1016/j.jbankfin.2006.10.029

[18] Olweny, T. The Reliability of Dividend Discount Model in Valuation of Common Stock at the Nairobi Stock Exchange. International Journal of Business and Social Science, 2(6), 2011, 127-141. doi:DOI: 10.30845/ijbss

[19] O'Neil, W. How to Make Money in Stocks: : A Winning System in Good Times and Bad (Fourth Edition ed.).1990. McGraw-Hill.

[20] Safari, M. Dividend Yield and Stock Return in Different Economic Environment: Evidence from Malaysia. SSRN, 9.2009, doi:https://dx.doi.org/10.2139/ssrn.1503799

[21] V, S., \& Paul, B. Dividend Discount Model (DDM): A study based on select companies from India. Project: Part of my PHD, 2019, Christ Institute of Management, Christ Trust, Lavasa. Retrieved from https://www.researchgate.net/publication/331648174_Dividend_Discount_Model_DDM_A_st udy_based_on_select_companies_from_India

[22] Warren, G. What Does it Mean to Be a Long-Term Investor?2016, Retrieved from The Brandes Institute: https://www.brandes.com/docs/default-source/brandes-institute/2016/whatdoes-it-mean-to-be-a-long-term-investor 